\title{
The Effect of Leadership on Work Stress at PT. Karya Anugerah Bersama Permai (PT. KABP)
}

\author{
Niarita Bukit \\ Faculty of Economics, Universitas Sisimangaraja XII Tapanuli, Indonesia \\ mniaritabukit@gmail.com
}

\begin{abstract}
The purpose of this study was to determine the influence of leadership on work stress and to analyze the influence of leadership on work stress at PT. Karya Anugerah Bersama Permai (PT. KABP). The type of research used in this research is explanatory research using a quantitative approach. The population and sample in this study were all employees who worked at PT. Karya Anugerah Bersama Permai (PT. KABP) totaling 36 people. The analytical technique used is descriptive statistical analysis. The results of research conducted with SPSS 20.0 indicate that leadership has a significant influence on work stress as evidenced by a partially significant test ( $t$ test) with a significance value obtained $0.00<0.05$ and a $t$ value of $t$ table 1.69, namely the t-count value of leadership is 11,053. The results of simple linear regression coefficients, obtained the equation $Y=3.389+1.050 X$ with an $R$ Square value of 0.782 so it can be concluded that the leadership variable has a positive and significant influence of $78.2 \%$ on work stress, while the remaining $21.8 \%$ is influenced by factors other.
\end{abstract}

\section{Keywords}

leadership, job stress; employee performance

\section{Introduction}

The activities of a company or organization are very dependent on the quality of human resources owned by each company. Without good human resources, the company's goals that have been set cannot run effectively and efficiently. A successful company can make human resources or employees able to work safely and comfortably so that employees can work professionally and optimally. Making human resources to be able to work professionally requires the right strategy from the company or organization so as not to put excessive pressure on employees because humans have reason, knowledge, emotions and feelings that are not easy to regulate and control.

Human resources are the basis and key of all organizational resources. Quality human resources have knowledge, skills, competencies, entrepreneurship and excellent physical and mental health, are talented, have a work ethic and high work motivation that can make an organization different between success and failure. Human resource development is an effort to develop the quality or ability of human resources through the process of planning education, training and management of personnel or employees to achieve an optimal result (Notoatmodjo in sulasmi, 2020). The development of human resources through the cultivation of achievement motivation is one of the contributions in improving the quality of human resources. (Werdhiastutie, A. 2020)

One of the reasons why companies cannot run effectively and efficiently is excessive stress levels for human resources owned by the organization or company. In general, it is natural that every job has pressure at work, but everyone must have a limit to work stress or their respective portions. Work stress is an allegation that comes from 
external or internal processes that have an impact on a person's level of physical and psychological tension to the limit or limits of the employee's ability. Feelings that make employees feel pressured or feel pressured in the face of work.

One of the triggers for the emergence of work stress for employees is the lack of good leadership techniques owned by the company or organization. In this case, there are still many organizations or companies that have not been able to apply good leadership methods in order to minimize the emergence of work stress for employees. The existence of a leader in an organization or company aims to carry out the company's goals well because there are people who move and are moved. Luthans (2006) in Yulia et al (2017) said that work stress is referred to as an adaptive response to external situations that cause physical, psychological, and or behavioral deviations from organizational members.

According to Handoko in Fadhilah Nurul (2016) reveals that many factors can cause work stress including the quality of clear supervision as well as Robbin in Fadhilah Nurul (2016) which describes that the potential source of stress is due to organizational factors, namely leadership style. This condition will have an impact on a person's psychology, including feelings of anxiety, moodiness and even no less important is reduced job satisfaction which has an impact on one's performance.

Based on this definition, it shows that the influence of a person's leadership in leading an organization or company has a significant impact on the performance and psychology of the employees. Angga in Fadhilah Nurul (2016) states that leadership is the ability to influence other parties through communication both directly and indirectly with the intention of moving people so that they are fully understanding, aware and willing to follow the leader's will. Hersey and Blanchard (1995) in Prayatna et al (2016) a person's leadership is a pattern of behavior shown by that person when influencing the activities of others.

This shows that the role of leadership really has a big impact on the performance of employees in an organization or company including morale, motivation and morale. With this ability, leaders can guide their employees to be able to do the work they want and be directed to achieve these goals. To achieve this goal, the role of leadership to create good employee performance is something that is needed by the organization.

PT. Karya Anugerah Bersama Permai (PT. KABP) which is engaged in the asphalt industry certainly requires maximum employee performance. In producing maximum performance, of course the level of work stress created will affect the performance of the employee. As a company with a high production capacity, the role of employees as an important factor in the production process is highly considered. So to get low work stress, it is necessary to have good leadership so that it can reduce the pressure and stress felt by employees at PT. Karya Anugerah Bersama Permai and can provide maximum results. This study aims to see the effect of leadership variables on job stress felt by employees at PT. Karya Anugerah Bersama Permai (PT. KABP).

\section{Research Methods}

This study uses quantitative data analysis and uses statistical formulas. This study uses a quantitative approach to answer the formulation of the problem in the study, and perform measurement techniques on certain variables so as to produce conclusions that can be generalized. Analysis of the data used is using Statistical Product and Service Solutions (SPSS) 20.0 model. 
The research was conducted at PT. Karya Anugerah Bersama Permai (PT. KABP) which is located at Jl. Ringroad Gontingbulu Sosorgonting Humbang Hasundutan Regency. The population and samples of this study are all permanent employees at PT. KABP totaling 36 people. Data collection techniques sourced from primary data in the form of a questionnaire. Questionnaires are a form of tool used to connect research actors with respondents in achieving data collection objectives.

The data analysis technique is carried out through several processes, starting from the measurement model which aims to assess the validity and reliability of the questions in the questionnaire. Then the data analysis is continued with a structural model that aims to describe the relationships that exist between the variables. Then tested by simple linear coefficient analysis and the existence of hypothesis testing to prove the significance of the support of the hypothesis by comparing the values of T-table and T-statistics. The final stage, testing the coefficient of determination ( $\mathrm{R}$ Square) which aims to measure the proportion or percentage of the model's ability to explain the dependent variable. The coefficient of determination ranges from zero to one ( $\left.\begin{array}{lll}0 & R & 1\end{array}\right)$. If the $R$ Square is getting bigger (closer to one), it can be said that the leadership (X) is large towards the independent variable (Y).

\section{Results and Discussion}

\subsection{Research Instrument Test Results a. Validity Test}

Table 1. Results of the Leadership Variable Validity Test

\begin{tabular}{|c|c|c|}
\hline Item Number & Results & Description \\
\hline Item 1 & 0,780 & Valid \\
\hline Item 2 & 0,797 & Valid \\
\hline Item 3 & 0,773 & Valid \\
\hline Item 4 & 0,718 & Valid \\
\hline Item 5 & 0,837 & Valid \\
\hline
\end{tabular}

Source: SPSS Data Processing Results (2021)

Based on the results of the calculation and validity testing above, it was found that from the research item testing conducted on 36 respondents that all indicators of the leadership variable met the validity standard with a value above 0.5 for each research indicator item.

Table 2. Employee Performance Validity Test Results

\begin{tabular}{|c|c|c|}
\hline Item Number & Results & Description \\
\hline Item 1 & 0,872 & Valid \\
\hline Item 2 & 0,603 & Valid \\
\hline Item 3 & 0,842 & Valid \\
\hline Item 4 & 0,880 & Valid \\
\hline Item 5 & 0,850 & Valid \\
\hline
\end{tabular}

Source: SPSS Data Processing Results (2021) 
Based on the results of the calculation and validity testing above, it was found that from the research item testing conducted on 36 respondents that all indicators of work stress variables met the validity standard with a value above 0.5 for each research indicator item.

\section{b. Reliability Test}

Table 3. Reliability Test Results

\begin{tabular}{|c|c|c|c|}
\hline Variable & $\mathrm{R}_{\text {count }}$ & $\mathrm{r}$ table 5\% (36) & Description \\
\hline Leadership (X) & 0,824 & 0,60 & Reliabel \\
\hline Job Stress (Y) & 0,873 & 0,60 & Reliabel \\
\hline
\end{tabular}

Source: Processed Data of SPSS (2021)

The results of the reliability test obtained the reliability coefficient value of the Leadership variable $(\mathrm{X})$ of 0.824 and the Work Stress variable $(\mathrm{Y})$ of 0.873 . Based on the value of the reliability coefficient, it is concluded that all variables in this study are reliable or consistent.

\subsection{Simple Linear Regression Analysis}

Hypothesis testing in this study using the SPSS 20 for windows program by testing simple linear regression which is an analysis to determine the magnitude of the influence between the independent variable and the dependent variable. This study uses tests conducted with a significant level of $5 \%$.

Table 4. Simple Linear Regression Test Results Coefficients $^{\mathbf{a}}$

\begin{tabular}{|rl|r|r|r|r|r|}
\hline \multirow{2}{*}{ Model } & \multicolumn{2}{|c|}{$\begin{array}{c}\text { Unstandardized } \\
\text { Coefficients }\end{array}$} & $\begin{array}{l}\text { Standardized } \\
\text { Coefficients }\end{array}$ & \multirow{2}{*}{ T } & \multirow{2}{*}{ Sig. } \\
\cline { 2 - 5 } & \multicolumn{1}{|c|}{ B } & Std. Error & \multicolumn{1}{c|}{ Beta } & & \\
\hline \multirow{2}{*}{1} & (Constant) & 3.389 & 1.561 & & 2.170 & .037 \\
& Leadership & 1.050 & .095 & .884 & 11.053 & .000 \\
\hline
\end{tabular}

a. Dependent Variable: Work stress

Source: SPSS Data Processing Results (2021)

From the table above, the results of the regression equation are $3.389+1.050 \mathrm{x}$

1. A constant of 3.389 means that if the leadership variable is zero, the value of work stress is 1.050 units.

2. The leadership variable has a positive value of 1.050 . This means that every 1 unit increase in leadership will have an effect on increasing work stress by $3,389+1,050$ (1) $=4,439$. This gives an understanding that the higher and better the leadership, the lower the work stress experienced by employees.

\subsection{Coefficient of Determination}

Testing the coefficient of determination $\left(\mathrm{R}^{2}\right)$ is used to measure the proportion or percentage of the model's ability to explain the dependent variable. The coefficient of determination ranges from zero to one $\left(0 \leq \mathrm{R}^{2} \geq 1\right)$. If $\mathrm{R}^{2}$ is getting closer to one, it can be said that the influence of the independent variable $(\mathrm{X})$ is large on the dependent variable (Y). 
Table 5. Coefficient of Determination Test Results

Model Summary

\begin{tabular}{|l|r|r|r|r|}
\hline $\begin{array}{l}\text { Mode } \\
1\end{array}$ & R & R Square & $\begin{array}{c}\text { Adjusted R } \\
\text { Square }\end{array}$ & $\begin{array}{c}\text { Std. Error of } \\
\text { the Estimate }\end{array}$ \\
\hline 1 & $.884^{\mathrm{a}}$ & .782 & .776 & 1.99734 \\
\hline
\end{tabular}

a. Predictors: (Constant), Kepemimpinan

Source: SPSS Data Processing Results (2021)

Based on the table above, the R-Square value is 0.782 . This means that $78.2 \%$ of the variation in the value of work stress is determined by the role of the variation in the value of leadership. So it can be concluded that the contribution of leadership value is $78.2 \%$ while $21.8 \%$ is the contribution of other variables not examined in the study.

\subsection{Hypothesis}

\section{T-test of Leadership Variables on Job Stress}

This analysis is to determine the effect of independent variables individually on the dependent variable. Ha is accepted, if $\mid$ tcount $\mid>$ ttable and if sig $<\alpha ́(0,05)$.

Table 6. T-test results

Coefficients $^{\text {a }}$

\begin{tabular}{|rl|r|r|}
\hline \multicolumn{2}{|l|}{ Model } & \multicolumn{1}{c|}{$\mathrm{T}$} & \multicolumn{1}{c|}{ Sig. } \\
& & & \\
\hline \multirow{2}{*}{1} & (Constant) & 2.170 & .037 \\
& Leadership & 11.053 & .000 \\
\hline
\end{tabular}

a. Dependent Variable: Work stress

Source: SPSS Data Processing Results (2021)

Based on hypothesis testing using the t-test, it is known that the t-test value of the leadership variable is 8.411 because the t-test $>\mathrm{t}$-table or $11.053>1.67$, then there is an influence between the leadership variables on work stress.

\subsection{Discussion}

The effect of leadership on work stress is seen through a questionnaire, with variable $\mathrm{x}$ as leadership, and variable $\mathrm{y}$ as work stress.

\section{a. Leadership}

The measurement model on the leadership variable to see the picture of leadership applied to PT. Karya Anugerah Bersama Permai (PT. KABP). The results of this descriptive analysis include the overall responses of respondents to the 5 items contained in the leadership variable, namely traits, habits, temperament, character, and personality, obtained an average total leadership variable (X) of 3.32 and this means that most of the respondents agreed to the leadership variable (X) at PT. Karya Anugerah Bersama Permai (PT. KABP). 
Table 7. Summary of Analysis Per Indicator of Leadership Variables

\begin{tabular}{|l|l|l|l|}
\hline No & Indicator & Amount & Average \\
\hline 1 & Traits & 143 & 3,97 \\
\hline 2 & Habits & 96 & 2,66 \\
\hline 3 & Temprament & 90 & 2,50 \\
\hline 4 & Character & 127 & 3,52 \\
\hline 5 & Personality Amount & 141 & 3,92 \\
\hline \multicolumn{2}{r}{ Am } & 597 & 3,32 \\
\hline
\end{tabular}

Source: SPSS Data Processing Results (2021)

Based on the five indicators above, it can be said that the leadership applied to PT. Karya Anugerah Bersama Permai (PT. KABP) is in the sufficient category. The application of good leadership is categorized sufficiently, this shows that the implementation has been carried out well.

\section{b. Job Stress}

The measurement model on the work stress variable is used to see the description of work stress at PT. Karya Anugerah Bersama Permai (PT. KABP). Overall respondents' responses to the 5 items contained in the work stress variable, namely pressure/time pressure, interpersonal and intergroup conflicts, work specialization, excessive workload and unfavorable working conditions, were obtained as the average total work stress variable (Y) of 2.70 and this means that most of the respondents agreed to the work stress variable (Y) at PT. Karya Anugerah Bersama Permai (PT. KABP).

Table 8. Results of Analysis of Work Stress Variable Indicators

\begin{tabular}{|l|l|l|l|}
\hline No & Indicator & Amount & Average \\
\hline 1 & Pressure/ Time Pressure & 99 & 2,75 \\
\hline 2 & Interpersonal and Intergroup Conflicts & 110 & 3,05 \\
\hline 3 & Work Specialization & 88 & 2,44 \\
\hline 4 & Excessive Workload & 87 & 2,42 \\
\hline 5 & Unfavorable Working Conditions & 101 & 2,80 \\
\hline \multicolumn{2}{|c|}{ Amount } & 485 & 2,70 \\
\hline
\end{tabular}

Source: SPSS Data Processing Results (2021)

Based on the five indicators above, it can be said that the work stress felt by employees of PT. Karya Anugerah Bersama Permai (PT. KABP) is in the low category. Management of work stress which is categorized as low indicates that the level of work stress felt by employees is low.

\section{c. The Effect of Leadership on Job Stress}

Respondents' responses to each variable, namely leadership and work stress, showed that respondents agreed to leadership and work stress. This is supported by a simple linear analysis conducted at PT. Karya Anugerah Bersama Permai (PT.KABP) which shows that leadership has an influence on work stress felt by employees at the company, both good and bad leadership.

The results of research conducted through the Statistical Product and Service Solution (SPSS) show that there is a positive and significant influence between leadership on the work stress variable. These results are comparable to the results of simple linear 
coefficient analysis on testing the influence of leadership variables on work stress, the results show that the coefficient of influence of leadership is 1.050 on work stress variables. Furthermore, the results of the hypothesis test to measure the partial significance which shows the T-statistic value is 11,053 with a t-table value of 1.67 , then t-statistic $>\mathrm{t}$ table (11.053>1.67) and a significance of 0.000 , then $\mathrm{H} 0$ is rejected, so that it can be said that the organizational culture variable has a positive and significant effect $(0.000<0.05)$ on work stress at PT. Karya Anugerah Bersama Permai (PT. KABP).

Testing the coefficient of determination, the result of the $\mathrm{R}$ Square value is 0.782 . These results indicate that the contribution of the influence of leadership on job stress at PT. Karya Anugerah Bersama Permai (PT. KABP) is $78.2 \%$ with $21.8 \%$ influenced by other variables outside the study.

\section{Conclusion}

Based on the research conducted, it can be concluded that the influence of leadership on work stress, concluded that the effect is positive and significant. This can be seen from the average value of the question scores on the leadership variable categorized in the moderate level because it is at 3.32. This value indicates the application of leadership at PT. Karya Anugerah Bersama Permai (PT. KABP) is categorized in the medium level. In work stress, the average value of the question scores is categorized as low because it is at 2.70. This value shows that work stress is good but not optimal. The application of leadership has a positive and significant effect on work stress at PT. Karya Anugerah Bersama Permai (PT. KABP) is about $78.1 \%$ and the remaining $21.8 \%$ is influenced by factors not examined in this study. This can be seen from the test of the coefficient of determination and the value of R Square $=0.675$. Suggestions that can be given are PT. Karya Anugerah Bersama Permai (PT. KABP) can also develop programs that can help employees overcome their problems, pay attention to an adequate employee benefits system and pay attention to and maintain the stability of work stress caused by individual, group and organizational factors.

\section{References}

Alfattama, L.C., (2019). Pengaruh Kepemimpinan dan Stres Kerja Terhadap Kinerja Pegawai Melalui Kepuasan Kerja Sebagai Variabel Intervening PT Gardha Jaya Sakti di Surabaya. Soetomo Business Review, 2(1), 60-73

Bahri Mawarni. (2019) . Pengaruh Gaya Kepemimpinan dan Stres Kerja Terhadap Kinerja Karyawan Departemen Pulp Making 8\&9 PT Indah Kiat Tbk Perawang. UIN SUSKA RIAU. Skripsi.

Diansyah. (2016). Pengaruh Gaya Kepemimpinan dan Stres Kerja Terhadap Kinerja Pegawai (Studi Kasus Dinas Kesehatan Kabupaten Jember). Bisma, Jurnal Bisnis dan Manajemen, 10(3), 307-318

Nandang. (2021). Pengaruh Lingkungan Kerja dan Gaya Kepemimpinan Terhadap Stres Kerja Pada Bagian Quality Control Assy di PT. XXX. Jurnal Manajemen \& Bisnis Kreatif, 6(2). 60-80

Prayatna, A.H., Subudi, M. (2016). Pengaruh Gaya Kepemimpinan Terhadap Stres Kerja dan Kepuasan Kerja Karyawan pada Fave Hotel Seminyak. E-Journal Management Unud, 5(2), 845- 872. 
Rivai,Veithzal dan Deddy Mulyadi. (2010). Kepempinan dan Perilaku Organisasi.Raja Grafindo Persada:Jakarta

Robbins,Stephen.Judge,Timothy. (2008). Perilaku Organisasi.Jakarta:Salemba Empat

Rochamanasari Dina. (2013). Analisis Pengaruh Stres Kerja dan gaya Kepemipinan Terhadap Kinerja Pegawai Perusahaan Daerah Bank Perkreditan Rakyat BLL Kabupaten Demak. Universitas Diponegoro

Septiana, A, Harini, S, Sudarijati. (2018). Pengaruh Stres Kerja dan Kepemimpinan Terhadap Kinerja Karyawan. Jurnal Sosial Humaniora, 9(1), 34-47.

Susilawati, et al. (2020). Impact of COVID-19's Pandemic on the Economy of Indonesia. Budapest International Research and Critics Institute-Journal (BIRCI-Journal). P.n 1147-1156.

Utami,L. Sarianti, R. Mesta, H.A. (2015). Pengaruh Gaya Kepemimpinan dan Stress Kerja Terhadap Kinerja Pegawai pada Dinas Pekerjaan Umum Kota Padang. Jurnal Praktik Bisnis, 4(1), 51-60.

Werdhiastutie, A. et al. (2020). Achievement Motivation as Antecedents of Quality Improvement of Organizational Human Resources. Budapest International Research and Critics Institute-Journal (BIRCI-Journal). P. 747-752.

Yulia,E., Mukzam, D. (2017). Pengaruh Gaya Kepemimpinan Terhadap Stres Kerja dan Kinerja Karyawan (Studi pada Karyawan PTPN XI Unit Usaha PG Semboro). Jurnal Administrasi Bisnis, 51(2), 22-31

http:www.lem-telko.co.id/stress-kerja/ diakses pada tanggal (7 April 2021)

(http://kesehatan.kompas.com), diakses pada tanggal (10 April 2021) 